Dr n. hum. Magdalena Rzadkowolska

Zespół Szkół Ekonomiczno-Turystyczno-Hotelarskich

im. Wł. Grabskiego w Łodzi

\title{
KULTURA CZYTELNICZA UCZNIÓW ZESPOŁU SZKÓŁ EKONOMICZNO-TURYSTYCZNO- HOTELARSKICH IM. WŁADYSŁAWA GRABSKIEGO W ŁODZI
}

\begin{abstract}
Streszczenie
Problem kultury czytania różnych środowisk i wieku stale interesuje badaczy. Zwłaszcza, że odsetek czytelników maleje. Obecnie tylko 40\% Polaków czyta książki. Czy uczniowie szkół technicznych chcą czytać książki? Jakie są ich zainteresowania czytelnicze? Czy rodzice zachęcają ich do czytania? Pytania te zostały zadane w ankietach przeprowadzonych wśród studentów Zespołu Szkół Ekonomiczno-Turystyczno-Hotelarskich im. Władysława Grabskiego w Łodzi, jednej z najlepszych szkół średnich w Polsce i w tym regionie. Część teoretyczna tego artykułu koncentruje się na zagadnieniach kultury książki i kultury czytania w Polsce. Opiera się na wynikach badań przeprowadzonych przez Bibliotekę Narodową w 2017 roku. Przedstawione dane podkreślają zainteresowania książkowe respondentów w wieku 15-24 lata. Według badań własnych Autorki kobiety czytają intensywnie, podczas gdy mężczyźni sporadycznie lub systematycznie. Młodzi czytelnicy najczęściej korzystają z domowych bibliotek lub wypożyczają książki od swoich rówieśników. Nie mają zwyczaju korzystania z bibliotek. Czytają powieści fantasy i kryminały. Niestety rodzice nie zachęcają młodych ludzi do czytania i nie kupują dla nich książek.
\end{abstract}

Słowa kluczowe: czytelnictwo, młodzież, zainteresowania czytelnicze

Umiejętność czytania jest warunkiem funkcjonowania współczesnego społeczeństwa. Dzięki niej ludzie mogą szybko i sprawnie komunikować się między sobą, 
wymieniać informacje, dzielić się doświadczeniem, spostrzeżeniami i przekazywać uczucia. Zaś praktyki lekturowe od starożytności były świadectwem ludzkich obyczajów.

Wraz z poszerzaniem się środowisk, które nabywały umiejętności czytania i pisania, książka stała się elementem stylu życia wielu grup społecznych. Rozwiązania techniczne sprawiły, że książka stała się tania i była powszechnie dostępna. Rozwój form książki i nawyków lekturowych spowodował zainteresowanie czytelnictwem jako przedmiotem badań naukowych. Od XIX w. zaczęto opisywać i definiować kulturę czytelniczą. W Polsce po II wojnie światowej, w kręgu Instytutu Książki i Czytelnictwa Biblioteki Narodowej, ukształtowała się szkoła badań bibliologicznych, szczególnie dotyczących czytelnictwa. W XXI w. liczba czytających Polaków stała się istotnym zagadnieniem społecznym. Przez lata obserwowano spadek odsetka czytających, który od 2008 r. oscyluje wokół 40\%. Problem kultury czytelniczej różnych środowisk i grup wiekowych nieustannie interesuje badaczy, szukających odpowiedzi na pytania jak się ona kształtuje?

Autorka niniejszej pracy również zadała pytanie o przejawy kultury czytelniczej współczesnej młodzieży. Czy uczniowie szkoły ponadgimnazjalnej chcą czytać książki? Jakie są ich zainteresowania czytelnicze? Czy rodzice uczestniczą w procesie kształtowania kultury czytelniczej? Do badań ankietowych wybrano grupę uczniów uczęszczających do klas I-IV Zespołu Szkół Ekonomiczno-Turystyczno-Hotelarskich im. Władysława Grabskiego w Łodzi. Szkoła należy do grona najlepszych techników w regionie i 100 najlepszych placówek edukacyjnych w Polsce. Jej uczniowie osiągają najwyższe wyniki w nauce, aktywnie pracują w samorządzie uczniowskim i kołach zainteresowań.

Artykuł składa się z trzech części. Pierwsza została poświęcona teoretycznym zagadnieniom kultury książki i kultury czytelniczej. W oparciu najnowsze wyniki badań stanu czytelnictwa przeprowadzonych przez Bibliotekę Narodową przedstawiono w drugiej części informację o zainteresowaniu książką grupy respondentów w wieku 15-24 lata, ze szczególnym uwzględnieniem uczniów i studentów. Trzecia zawiera omówienie wyników badań.

\section{Kultura czytelnicza w świetle literatury przedmiotu}

Książka to historycznie uformowany przedmiot składający się z kart umocowanych w okładce, zwany kodeksem. Uważa się ją za „reprezentatywny produkt kultury druku" (Dunin 1998: 88); bywa traktowana przedmiotowo - jako wytwór zawierający tekst. Książka rozumiana jest także jako synonim dzieła literackiego (książka beletrystyczna), którą Umberto Eco nazywa „książką do czytania” (Hopfinger 
2005: 541). Najlepszą odpowiedź na pytanie czym jest książka, daje definicja Jana Muszkowskiego: „książka jest to produkt materializacji graficznej treści kulturalnych stanowiących pewną zamkniętą całość, podjętej w celu utrwalenia ich, przekazywania i rozpowszechnienia wśród ludzi” (Muszkowski 1972: 100).

Ekspresja książkowa daje autorowi wiele możliwości, pozwala na budowę luźną, niekonsekwentną, długie opisy, prowadzenie wielu wątków, nie liczy się z koniecznością zamknięcia lektury w określonym czasie. Równocześnie wymaga od odbiorcy wysiłku, własnego wkładu w percepcję utworu. Czytelnik ma możliwość wyboru lektury z produkcji wydawniczej całego świata (jedyną barierę stanowi znajomość języków obcych), autorów współczesnych i twórców z dawnych epok. Sam wybiera porę i miejsce lektury, ustala jej rytm; i co najważniejsze sam interpretuje utwór. Może zatrzymać się nad tekstem, sięgnąć do fragmentów już przeczytanych lub tych, do których jeszcze nie dotarł, wrócić do książki w dowolnym czasie po zakończeniu lektury.

Współczesna kultura rozumiana jest w kategoriach gry, odwołuje się do stwierdzenia Michela Foucault, że „tym, co archeologia chce odsłonić, jest w pierwszym rzędzie gra analogii i różnic, takich jakie zjawiają się na poziomach reguł formacyjnych; gra opisywania przy utrzymaniu całej specyfiki i dystansu różnych formacji dyskursywnych" (Foucault 1977: 197). Instrukcja gry w książkę stawia przed uczestnikiem jasne i proste reguły: umiejętność składania liter i znajomość zasad językowych oraz rozumne czytanie. Każda gra ma swój cel, przebiega według tych samych reguł. Grę w książkę uruchamia czytelnik, a jej istotą jest poddanie przyswojonego tekstu konfrontacji z życiowymi doświadczeniami, i którym towarzyszy dojrzewanie świadomości czytelniczej.

Niewiele wiemy o tym, co się dzieje z treścią książki po jej przeczytaniu. Zdaniem Romana Ingardena konkretyzacja dzieła jest rozciągnięta w czasie. On też $\mathrm{w}$ fenomenologicznej teorii dzieła literackiego ujawnił istnienie w nim miejsc niedookreślonych, niedokończonych wyglądów, opisów, które czytelnik w lekturze dopełnia. W tekście literackim zawarta jest jedynie dyrektywa sugerująca czytelnikowi zasadnicze kierunki odczytań (dopuszczających i wykluczających znaczeń tekstu) (Ingarden 1988: 79, 103).

Niegdyś literatura „mąciła w zbiorowej wyobraźni”. Spory o zawartość i wymowę dzieł literackich były namiętne, stanowiły jeden ze sposobów ustalania własnej tożsamości, jeden z trybów walki o miejsce w przestrzeni publicznej, model reagowania na nowe sposoby ekspresji. Dziś uważa się, że literatura piękna daje bogactwo przeżyć, stała się narzędziem poznawania rzeczywistości, ukazując ją nie w abstrakcyjnych i schematycznych uogólnieniach, lecz w konkretnych sytuacjach i ludziach. Fabuła jest pożywką dla wyobraźni, pomaga budować nastrój, upiększa życie, ale również pozwala je dramatyzować, mieszać prawdę i zmyślenia. Jednak 
głównym efektem procesu lektury jest rozwijanie wyobraźni, której towarzyszy wzbogacanie osobowości, zdobywanie wiedzy o świecie i inicjowanie twórczego myślenia (Por. Wojciechowski 2000: 100-104).

Termin kultura czytelnicza opisuje „integralny zespół zainteresowań, nawyków, sprawności, umiejętności i wiadomości czytelniczych, umożliwiający człowiekowi najkorzystniejsze dla wszechstronnego rozwoju jego osobowości i twórczego funkcjonowania w społeczeństwie obcowanie ze słowem drukowanym. Do podstawowych jej elementów należą: systematyczny kontakt z książką i prasą, umiejętność doboru lektury i korzystania z informacji, odpowiednia metoda czytania, dążność do posiadania własnego księgozbioru oraz umiejętne spożytkowanie treści lektur” (Encyklopedia oświaty i kultury dorostych 1986: 49).

Kulturę czytelniczą rozpatruje się $\mathrm{w}$ aspekcie społecznym oraz jednostkowym (psychologicznym). Pierwsze znaczenie dotyczy zjawisk i procesów związanych ze społecznym funkcjonowaniem książek i czasopism. Natomiast drugie jest wiązane z rozwojem osobowości czytelnika, który kształtują przekazy piśmiennicze. Jadwiga Andrzejewska badając zachowania czytelnicze wprowadziła pojęcie kultury czytelniczej jednostki. Jej zdaniem kulturę czytelniczą można „pojmować jako system dyspozycji motywacyjnych i instrumentalnych oraz wynikających z nich zachowań czytelniczych, umożliwiających człowiekowi wykorzystanie przekazów piśmienniczych w samorealizacji” (Andrzejewska 1980: 19).

Dyspozycje, do których odwołuje się Andrzejewska, stanowią „zespół tkwiących w jednostce warunków umożliwiających określone postacie działań i wyznaczających te działania" (Andrzejewska 1980: 19). Dzielą się na dyspozycje motywacyjne i instrumentalne. Dyspozycje motywacyjne to: przekonania, system wartości, cele, ideały, zamiłowania i zainteresowania. Do dyspozycji instrumentalnych należą m.in.: wiedza, umiejętności, nawyki i doświadczenia. Według Andrzejewskiej kultura czytelnicza to „system dyspozycji motywacyjnych i instrumentalnych oraz wynikających z nich zachowań czytelniczych umożliwiających człowiekowi wykorzystywanie przekazów piśmienniczych w samorealizacji”. Na zachowania czytelnicze składają się natomiast: aktywność czytelnicza, wybory i preferencje czytelnicze oraz procesy recepcji lektury. Zachowania czytelnicze uruchamiane są poprzez dyspozycje motywacyjne, do których należą: przekonanie o wartości czytania, potrzeba czytania, zamiłowanie czytania, zainteresowania czytelnicze, czy motywy czytania (Andrzejewska 1988: 311).

Potrzeba czytania oznacza uczucie braku tego, co ma jakąś wartość i tym samym podjęcie takich działań, które daną potrzebę zaspokoją. Połączenie trwałej skłonności do czytania z odczuwaniem przyjemności, to zamiłowanie do czytania. Zainteresowania czytelnicze obejmują czytanie określonego typu tekstów, np. wybranego gatunku literackiego, pisarza. Zainteresowania te ewoluują wraz z dojrzewaniem 
psychofizycznym i psychospołecznym. Stabilizują się dopiero w wieku dojrzałym. Wyróżnia się trzy stadia zainteresowań czytelniczych, związanych z etapami dorastania: wiek baśni, wiek robinsonady i wiek powieści realistycznej. Przejście przez nie warunkuje prawidłowy rozwój kultury czytelniczej młodzieży (Wajda 1979: 114-115).

Do powodów, dla których czyta się książki zalicza się nastawienie do czytanego tekstu oraz zaspokajanie potrzeb za jego pomocą. Mogą one mieć charakter instrumentalny, np. nakazów nauczycieli, wymagań wykonywanego zawodu, chęci zdobycia prestiżu człowieka oczytanego. Poprzez lekturę zaspokaja się potrzeby psychiczne, np. wiedzy i informacji, samokształcenia, wzorów postaw i zachowań, przeżyć estetycznych, kompensacji, partycypacji, terapii, rozrywki itd.

Zachowania czytelnicze uruchamiają następujące po sobie elementy: przekonanie wartości lektury, potrzeba czytania, zamiłowanie do czytania, zainteresowania czytelnicze oraz motywy czytania. Ich hierarchiczny układ wskazuje na rolę jaką odgrywają w pobudzaniu aktywności czytelniczej. Za najważniejszy czynniki determinujący czytanie uważa się przekonanie o wartości lektury. Antonina Kłoskowska (Kłoskowska 1972: 101) wyróżniła 4 typy czytelników, dla których lektura jest wartością $^{1}$ : 1 . uznawaną i odczuwaną, 2. uznawaną, lecz nieodczuwaną, 3. nieuznawaną, lecz odczuwaną, 4. nieuznawaną i nieodczuwaną.

Każdy z czterech wariantów opisuje podejście człowieka do lektury i charakteryzuje jego przekonanie o wartości lektury. Wariant pierwszy (lektura jako wartość uznawana i odczuwana) opisuje sytuację, w której człowiek podziela sądy otoczenia o wartości lektury (np. wynosi je z domu rodzinnego), a jednocześnie podczas pierwszych doświadczeń lekturowych spostrzega, iż zaspokaja ona jego potrzeby psychiczne. Gwarantuje on częste i owocne kontakty z książką w przyszłości. Drugi przypadek (lektura jako wartość uznawana, lecz nieodczuwana) opisuje sytuacje uczniów, którzy muszą zapoznać się z kanonem lektur, potrafią opisywać poszczególne dzieła i ich zalety, ale lekturę traktują instrumentalnie, nie podzielają zachwytu nauczyciela nad walorami utworów i nie czerpią radości z lektury. Ta sytuacja grozi całkowitym zaprzestaniem kontaktów z książką gdy skończy się obowiązek szkolny. Trzecia sytuacja (lektura jako wartość nieuznawana, lecz odczuwana) występuje wówczas, kiedy osoba podziela narzucone sądy otoczenia o bezwartościowości czytania, ale czerpie radość z lektury, która zaspokaja jej określone potrzeby psychiczne (kompensacja). Przypadek ostatni (lektura jako wartość nieuznawana i nieodczuwana) występuje wówczas, kiedy człowiek wynosi z domu negatywne stereotypy na temat czytania (strata czasu itp.), a jego pierwsze kontakty z książką wiążą się z niepowodzeniami. Utrwala się wówczas obraz książki i lektury jako

\footnotetext{
${ }^{1}$ Wartości uznawane weryfikuje się w oparciu o sądy grup odniesienia, natomiast wartości odczuwane na podstawie kryteriów indywidualnych.
} 
źródła cierpień i niepowodzeń. Czytelnicy z takim nastawieniem czytają jedynie z przymusu i najczęściej do chwili ustąpienia nakazu szkolnego.

Rozwój kultury czytelniczej zależy od środowiska społecznego, w jakim jest dziecko wychowywane. Fundamentalną rolę odgrywa dom rodzinny, czytający rodzice i krewni, obecność książek i prasy. To rodzice powinni świadomie wprowadzać dziecko w świat literatury już w najwcześniejszym okresie jego życia poprzez śpiewanie kołysanek i piosenek, opowiadanie i czytanie bajek, pokazywanie kolorowych książeczek, by następnie zaprowadzić dziecko do biblioteki, księgarni i zachęcać do korzystania ze zbiorów (por. Wojciechowski, op. cit., Papuzińska 1981; Koźmińska, Olszewska 2014).

Duży wpływ na zachowania czytelnicze ma środowisko rówieśnicze, które przekazuje informacje o tym, co warto przeczytać. Autorytet kręgu rówieśniczego przewyższa niejednokrotnie, autorytet rodziców czy nauczycieli. Grupa dostarcza wzorów ubierania się, wpaja pojęcia moralne, proponuje hierarchię wartości, kształtuje normy zachowania, narzuca określony język, kontroluje postępowanie członków itp. Wzrost autorytetu grupy rówieśniczej powodowany jest m.in. przez zmniejszenie wychowawczej roli rodziny. Również media społecznościowe są czynnikiem integracji kręgów rówieśniczych. Stanowią formę wspólnie przeżywanej rozrywki, dostarczają wzorów do masowego naśladowania.

\section{Praktyki czytelnicze młodzieży w 2017 r.}

Odpowiedź na pytanie jak kształtują się praktyki czytelnicze współczesnej młodzieży przynoszą wyniki badań czytelniczych przeprowadzonych przez Bibliotekę Narodową w 2017 r. Respondentów podzielono na kategorie wiekowe, uczniowie szkół ponadgimnazjalnych i studenci znaleźli się w grupie obejmującej osoby pomiędzy 15. a 24. rokiem życia²

Kobiety okazały się bardziej aktywnymi czytelniczkami od mężczyzn, 38\% w grupie najmłodszych badanych zadeklarowało, że w 2017 r. nie przeczytało ani jednej książki, mężczyzn było 49\%. Książek nie czytało 25\% uczniów i studentów (por. rys. 1).

\footnotetext{
${ }^{2}$ Cała część artykułu została opracowana na podstawie: Stan czytelnictwa w Polsce w 2017 r. [dok. elektron.]. - Tryb dostępu: https://www.bn.org.pl/download/document/1529572435. pdf [dostęp dnia 2018-09-01].
} 
Rys. 1. Czytanie książek w 2017 r. w grupie wiekowej 15-24 lata.

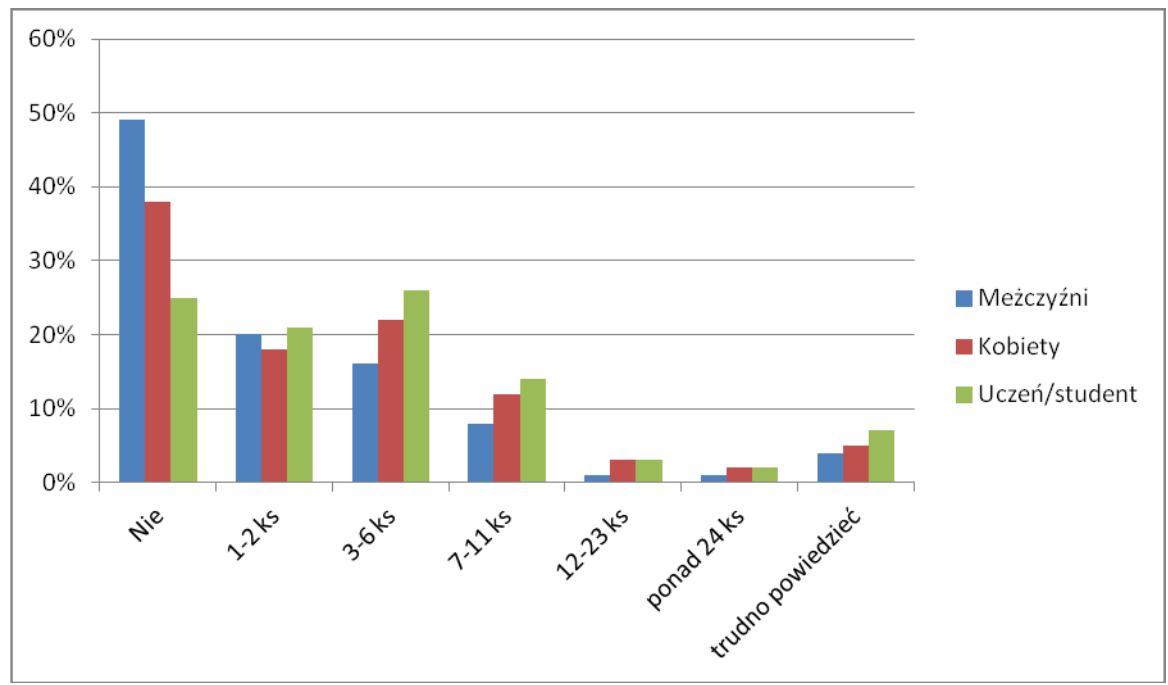

Źródło: Stan badań czytelnictwa w Polsce w 2017 r.

https://www.bn.org.pl/download/document/1529572435.pdf

Pobieranie nauki w szkole lub na uczelni wiąże się z tym, że częściej sięga się po książkę lub czyta co najmniej trzystronicowe teksty (por. Rys. 2).

Rys. 2. Czytanie książek na tle innych praktyk lekturowych w grupie wiekowej 15-24 lata.

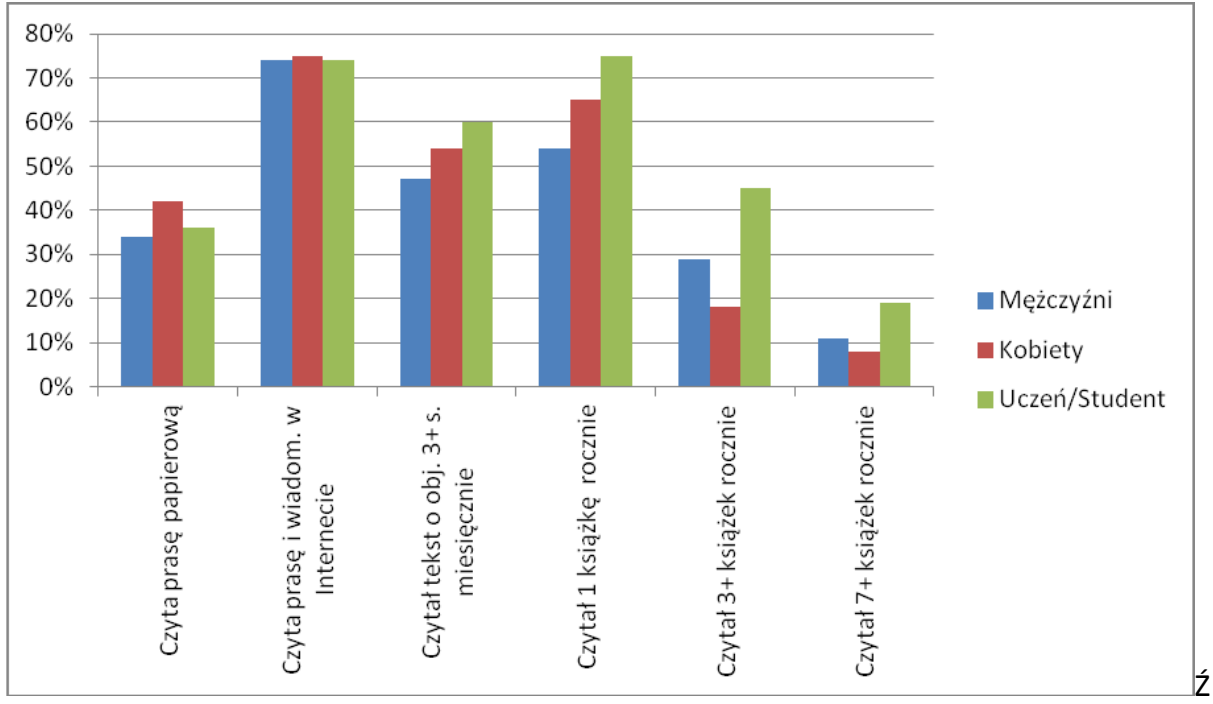


Źródło: Stan badań czytelnictwa w Polsce w 2017 r.

https://www.bn.org.pl/download/document/1529572435.pdf

W najmłodszej kategorii badanych (osób od 15. do 24. roku życia) na postawy czytelnicze w istotny sposób wpływa to, że jest się uczniem lub studentem. Wśród ogólnych deklaracji czytelniczych („czytał(a) przynajmniej 1 książkę w ciągu roku”) niemal połowę stanowią czytelnicy sporadyczni, czytający 1-2 książki rocznie. Odsetek deklarujących czytanie 7. i więcej książek w grupie uczniów i studentów nie przekracza połowy czytających ponad 3 książki. To właśnie grupa czytelników czytających częściej niż sporadycznie (7+), świadczy o większej intensywności czytania $\mathrm{w}$ danej grupie.

Rys. 3. Powody czytania w grupie wiekowej 15-24 lata.

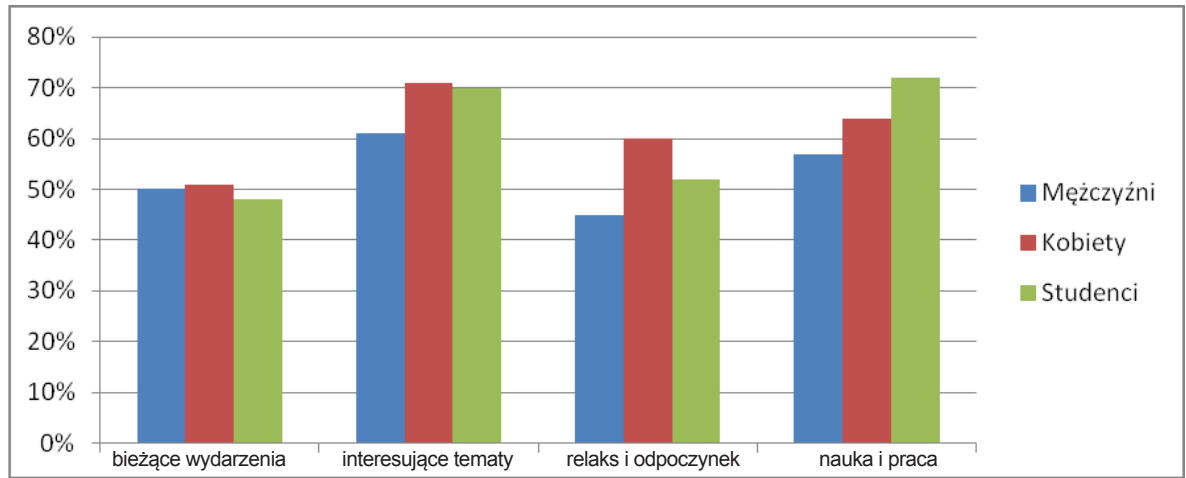

Źródło: Stan badań czytelnictwa w Polsce w 2017 r.

https://www.bn.org.pl/download/document/1529572435.pdf

W porównaniu z kobietami mężczyźni generalnie czytają mniej i wcześniej ograniczają swoją aktywność lekturową. Najczęściej sięgają po teksty związane z bieżącymi wydarzeniami. Natomiast kobiety znacznie częściej niż mężczyźni deklarują czytanie dla relaksu i odpoczynku. Czytanie jest źródłem odprężenia przede wszystkich dla tych, którzy są biegłymi czytelnikami i mają systematyczny kontakt z książkami. Dla uczniów i studentów nauka i praca są motywacją, która odgrywa pierwszoplanową rolę. $\mathrm{Na}$ etapie nauki szkolnej czytanie książek wiąże się z wymiernymi korzyściami, przekłada się na sukces edukacyjny. Zainteresowanie czytaniem literatury, przydatne w pomyślnym zdaniu egzaminów z języka polskiego, nie łączy się jednak z zainteresowaniem bieżącą sytuacją. W tej grupie rzadko czyta się, poszukując informacji o bieżących wydarzeniach (por. Rys. 3). 
Rys. 4. Źródła pozyskiwania książek w grupie 15-24 latków.

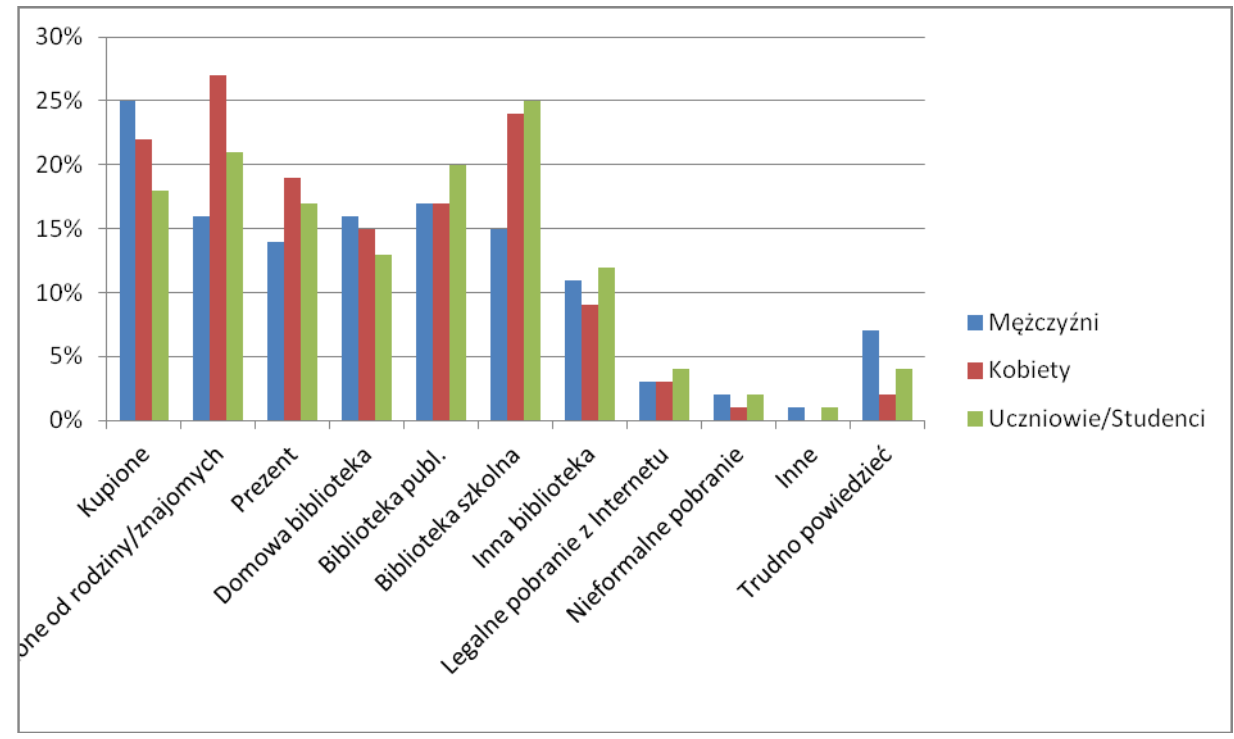

Źródło: Stan badań czytelnictwa w Polsce w 2017 r.

https://www.bn.org.pl/download/document/1529572435.pdf

Kobiety przewyższają mężczyzn pod względem intensywności praktyk lekturowych i czytelniczego zaangażowania. Książki czyta więcej kobiet niż mężczyzn. Kobiety bardziej lubią to robić i chętniej angażują się w towarzyszące książkom interakcje społeczne, co przekłada się na wyższy odsetek kobiet pożyczających książki od znajomych lub z biblioteki publicznej. Mężczyźni w wieku 15- 24 lat, w porównaniu do kobiet, pożyczają mniej książek od znajomych, to jednak w podobnym stopniu co one korzystają z bibliotek. Natomiast częściej jako źródło czytanych książek wskazują zakup. Wydaje się, że mężczyznom łatwiej jest podjąć decyzję o zakupie interesującej ich książki. W przypadku kobiet na niższą skłonność do kupowania książek, może wpływać również postrzeganie popularnych w tej grupie gatunków beletrystyki, jako literatury mniej wartościowej. Młode kobiety i młodzi mężczyźni w mniejszym stopniu korzystają z księgozbiorów domowych. Znaczenie tego źródła książek rośnie wraz z wiekiem. Podobnie wygląda sprawa prezentów, są doceniane dopiero w późniejszych fazach życia. Stoi to w sprzeczności z przekonaniem, że książka jest najodpowiedniejszym prezentem właśnie dla dzieci i osób młodszych niż starszych. Może książki, którymi starsze pokolenia obdarowują młodsze, nie znajdują uznania w oczach obdarowanych i lądując na półkach jako nieprzeczytane, nie pojawiają się w wynikach badań lub też są bardziej pożądane prezenty niż książki. 
Uczniów i studentów wyróżnia to, że mogą korzystać z bibliotek szkolnych i akademickich, co faktycznie czynią, przy okazji odwiedzając też biblioteki publiczne i pobierając książki z Internetu. Wpływa na to ich sytuacja finansowa, Nawet jeśli dorabiają lub pracują w czasie studiów, ich budżety, a przez to możliwości kupowania książek, są skromniejsze (por. Rys. 4). Wynika to z faktu, że edukacja nadal jest silnie związana z linearną lekturą tekstu stanowiącego samodzielną całość. Prawidłowość ta dotyczy zarówno kobiet, jak i mężczyzn. Autorzy opracowania sformułowali hipotezę, że obserwowana od lat wyższa pod każdym względem aktywność czytelnicza kobiet niż mężczyzn jest wynikiem między innym przeciętnie dłuższego w przypadku kobiet okresu pobierania nauki w szkole lub na uczelni.

\section{Omówienie badań własnych}

Poszukując odpowiedzi na postawione na wstępie pytanie o kulturę czytelniczą młodzieży, autorka postanowiła przeprowadzić badanie ankietowe uczniów Zespołu Szkół Ekonomiczno-Turystyczno-Hotelarskich im. Władysława Grabskiego w Łodzi. Historia szkoły sięga 1904 r., kiedy to została założona w Łodzi Miejska Szkoła Handlowa Męska. Obecnie jest to najlepsze technikum w regionie łódzkim, mieszczące się w pierwszej 100. polskich szkół ponadgimnazjalnych, placówka edukacyjna wyróżniana rokrocznie przez czasopismo „Perspektywy” złotą tarczą. Badanie przeprowadzono dnia 15 kwietnia 2018 r., wśród wybranych losowo uczniów klas I-IV obecnych tego dnia w szkole podczas lekcji 1-4. Wzięło w nim udział 68 osób, 39 kobiet i 29. mężczyzn w wieku między 16. a 20. rokiem życia.

Autorka opracowała kwestionariusz ankietowy, w formularzu zamieszczono metryczkę, by respondent podał swoją płeć i wiek. Zasadnicza część ankiety składała się z 14. pytań, 12. zamkniętych i 2. otwartych. Pytania 1-2 (zamknięte) dotyczyły wielkości domowego księgozbioru uczniów i liczby ich własnych książek. W kolejnym badani mieli określić, ile książek przeczytali w roku kalendarzowym 2017. W pytaniu 4 mieli wskazać jakie typy książek preferują. Pytanie 5. odnosiło się do interakcji społecznych czytelników, z kim najchętniej rozmawiają o swoich lekturach. Kafeteria odpowiedzi obejmowała rówieśników, rodzeństwo, rodziców, krewnych, nauczycieli, bibliotekarzy, inne osoby dorosłe. W przypadku tych pytań (4-5) respondenci mieli możliwość wyboru kilku odpowiedzi. Pytanie 6. dotyczyło oceny zasobów biblioteki szkolnej, do której powinni kierować swoje kroki nie tylko po lekturę obowiązkową. Kolejne, 7. pytanie miało charakter otwarty. Respondenci mogli się wypowiedzieć, o jakie gatunki, tytuły czy autorów, należy wzbogacić szkolny księgozbiór. Pytanie 8., zamknięte, dotyczyło oceny zestawu lektur szkolnych, jest to bowiem teren odwiecznej walki nauczycieli i uczniów. Ci pierwsi 
starają się przekonać młodzież do pożytków płynących z czytania klasyki literatury polskiej i obcej, ci drudzy buntują się przeciw temu. Dlatego też w odpowiedzi na pytanie 9., otwarte, badani mieli wskazać jakie książki chcieliby czytać w zamian narzuconego odgórnie kanonu. W pytaniu 10., zamkniętym, respondenci mieli wskazać, skąd pochodzą książki, które czytają w wolnym czasie. Zaproponowano zestaw 11. odpowiedzi, badani mogli wybrać kilka z nich. Zmieniają się nawyki lekturowe, prócz tradycyjnych edycji papierowych sięga się do źródeł cyfrowych. W pytaniu 11 postawiono kwestię wykorzystywania do czytania telefonów komórkowych, tabletów, laptopów, komputerów stacjonarnych i czytników ebooków. Pytania 12 i 13 miały wskazać udział rodziców w kształtowaniu kultury czytelniczej ich dzieci. Pytanie 12 przynieść informacje o tym, czy rodzice zachęcają do czytania. A pytanie 13 - czy czynią to poprzez kupowanie książek. Książka wciąż uchodzi za jeden z najczęściej kupowanych prezentów. Dlatego na koniec zapytano uczniów, czy uważają, że jest to dobry upominek dla nich.

Ponieważ dla kształtowania kultury czytelniczej znaczenie ma dostęp do książek, zapytano respondentów o wielkość księgozbiorów domowych (pytanie 1) i o liczbę ich własnych książek (pytanie 2). Według szacunków uczniów ich domowe biblioteki nie są duże. Jedynie 16. badanych deklaruje, że mają w domu ponad 150 książek, 22. osoby deklarują posiadanie przez rodzinę 50.-150. książek, 10 osób ma 20-50, 15 między 5 a 20 i przypadku 5 osób księgozbiór domowy nie przekracza 5 książek (por. Rys. 5).

Rys. 5. Wielkość księgozbiorów domowych.

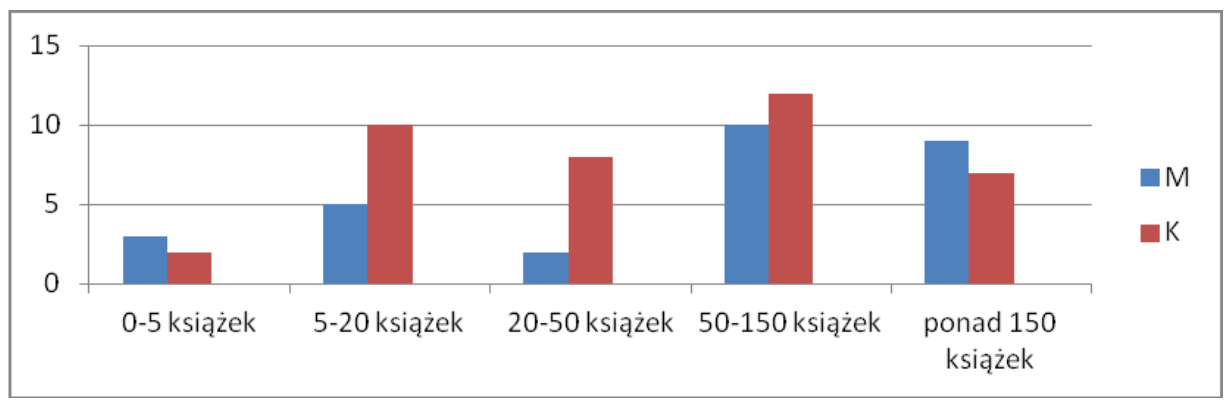

Źródło: Opracowanie własne.

W przypadku własnych zbiorów książkowych 25 kobiet i 15 . mężczyzn deklaruje, że posiada do 50. woluminów, 6 kobiet i mężczyzna posiadają od 50. do 150. książek. Nikt z badanych nie zgromadził ponad 150. książek. Natomiast 13. mężczyzn i 7 kobiet zadeklarowało posiadanie do 5 książek (por. Rys. 6). Maleje znaczenie księgozbiorów domowych, rodzice i respondenci nie gromadzą książek. 
Choć można zauważyć, że kobiety dążą do zakładania własnych bibliotek i mają większe kolekcje książek niż mężczyźni.

Rys. 6. Wielkość własnych księgozbiorów respondentów.

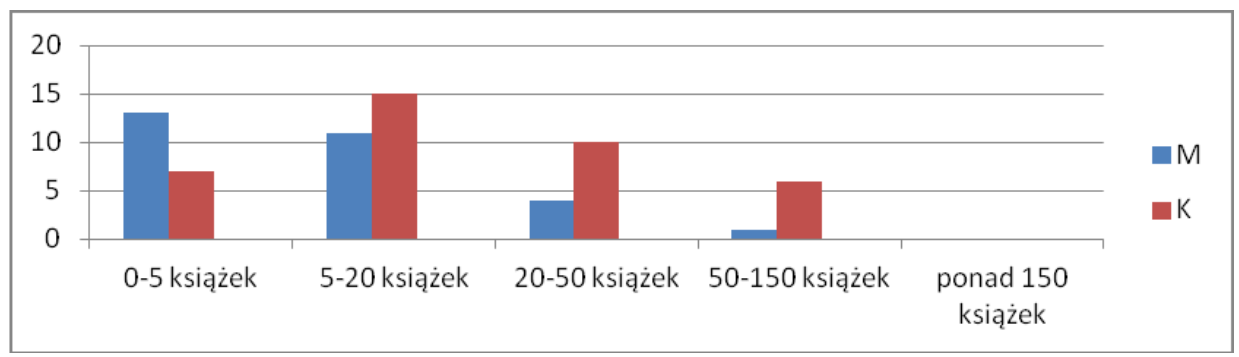

Źródło: Opracowanie własne.

Uczniowie nie sięgają chętnie po książki (pytanie 3.). 18 osób (11. mężczyzn i 6 kobiet) przeczytało w 2017 r. najwyżej 1 książkę. W grupie intensywnie czytających, którzy przeczytali ponad 21 woluminów znalazło się 7 osób (3 mężczyzn i 4 kobiety). Pozostali przeczytali od 2 (w tej grupie dominują mężczyźni) do 20 książek (przeważają kobiety; por. Rys. 7). Wśród czytelników dominują kobiety, to one wpływają na wielkość populacji czytającej.

Rys. 7. Liczba książek przeczytanych w 2017 r.

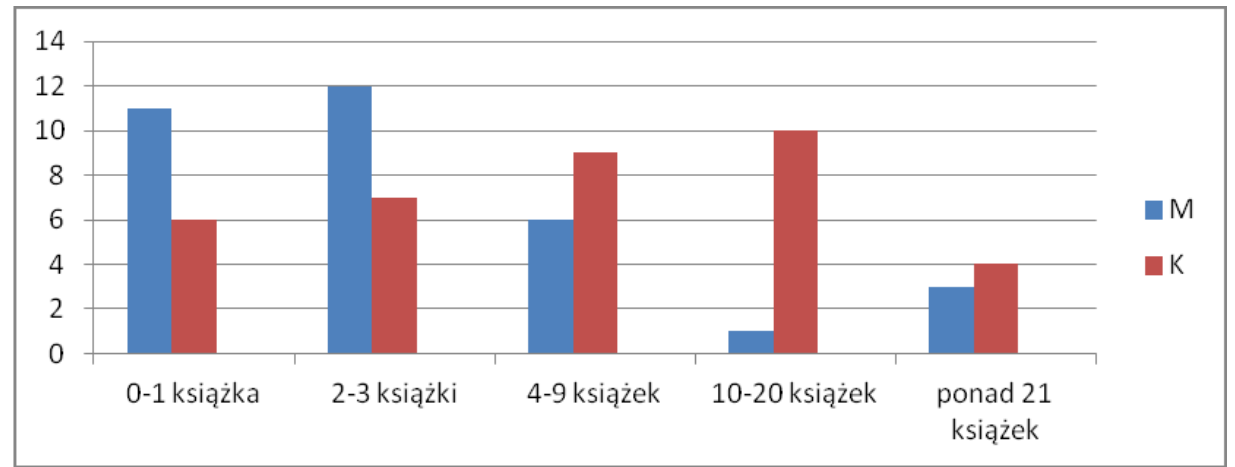

Źródło: Opracowanie własne.

W odpowiedzi na pytanie 4 młodzi czytelnicy podali, że najchętniej wybierają fantastykę, tak młodzieżową jak i dla dorosłych, oraz kryminały. Respondentki wybierają także literaturę obyczajową. Jak pokazuje Rys. 8 wśród czytelników niemal wszystkich wymienionych w pytaniu rodzajów literatury przeważają kobiety. Męska część badanej populacji sięga chętniej niż kobieca jedynie po komiksy i poradniki. 
Żadna uczennica nie zadeklarowała czytania literatury religijnej ani żaden uczeń wysokoartystycznej. Zwraca uwagę stosunek do lektur szkolnych. Nie czytają ich wszyscy uczniowie, jedynie 35\% badanej populacji, tyle samo kobiet co mężczyzn. Uczniowie chętnie sięgają po literaturę gatunkową, ich wskazania odzwierciedlają zainteresowania czytelnicze. Dla bibliotekarza to wskazanie jak kształtować zbiory biblioteczne, by przyciągnąć czytelników.

Rys. 8. Rodzaje literatury czytane przez respondentów.

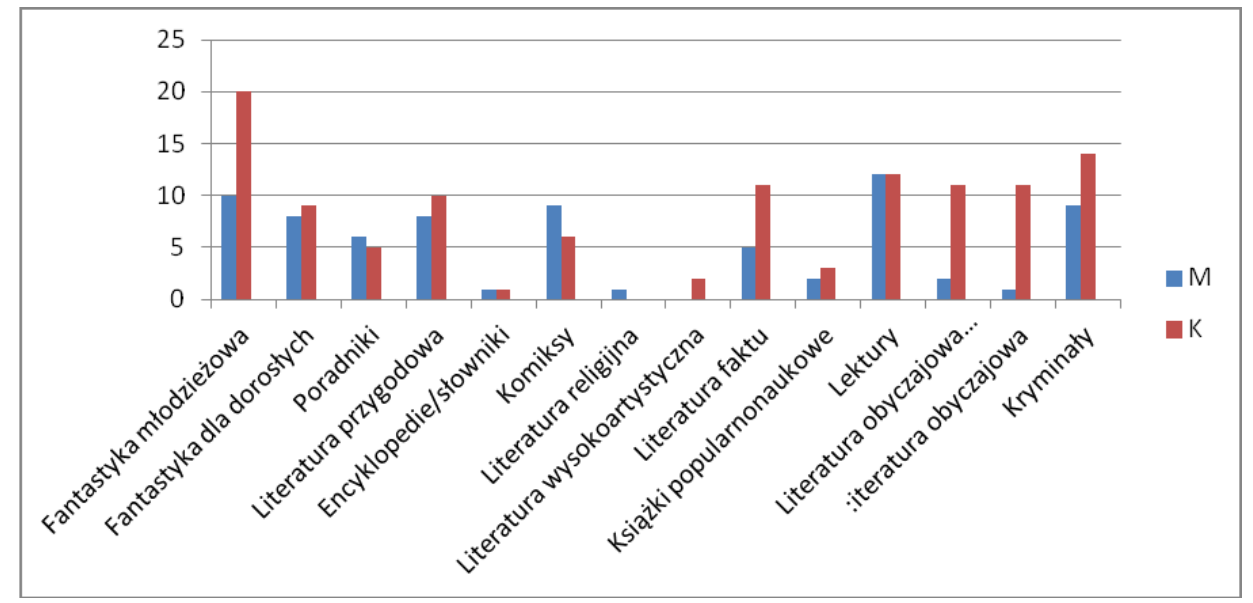

Źródło: Opracowanie własne.

O książkach częściej rozmawiają kobiety niż mężczyźni (pytanie 5). Obie płcie najchętniej dzielą się wrażeniami z lektury z rówieśnikami, w następnej kolejności wybierają na interlokutora mamę, a potem rodzeństwo. Ojciec nie jest postrzegany jako partner do prowadzenia takich rozmów. Zwraca uwagę, że uczniowie częściej niż uczennice wskazują nauczyciela jak rozmówcę, a uczennice - bibliotekarza (por. Rys. 9).

Powyższe dane poświadczają, że na kształtowanie wyborów czytelniczych największy wpływa ma grupa rówieśnicza, w dalszej kolejności dopiero rodzice i inni dorośli, z którymi spotyka się młody człowiek.

Szkoła chlubi się pozyskaniem w 2016 r. środków z Narodowego Programu Rozwoju Czytelnictwa na zakup nowych książek do biblioteki. Jednak uczniowie (tu znów przeważają kobiety), odpowiadając na pytanie 6, oceniają księgozbiór jako wystarczający. 32\% zadeklarowało, że nie zna zasobów szkolnej biblioteki (por. Rys. 10). Analiza kart czytelniczych potwierdza szczerość respondentów, większość uczniów podczas 4 lat nauki w szkole pojawia się w bibliotece sporadycznie lub nie 
korzysta z niej wcale ${ }^{3}$. Uczniowie nie postrzegają biblioteki szkolnej jako miejsca odgrywającego istotną rolę w procesie edukacji. Nie interesują się zgromadzonymi tam zasobami.

Rys. 9. Z kim badani rozmawiają o książkach?

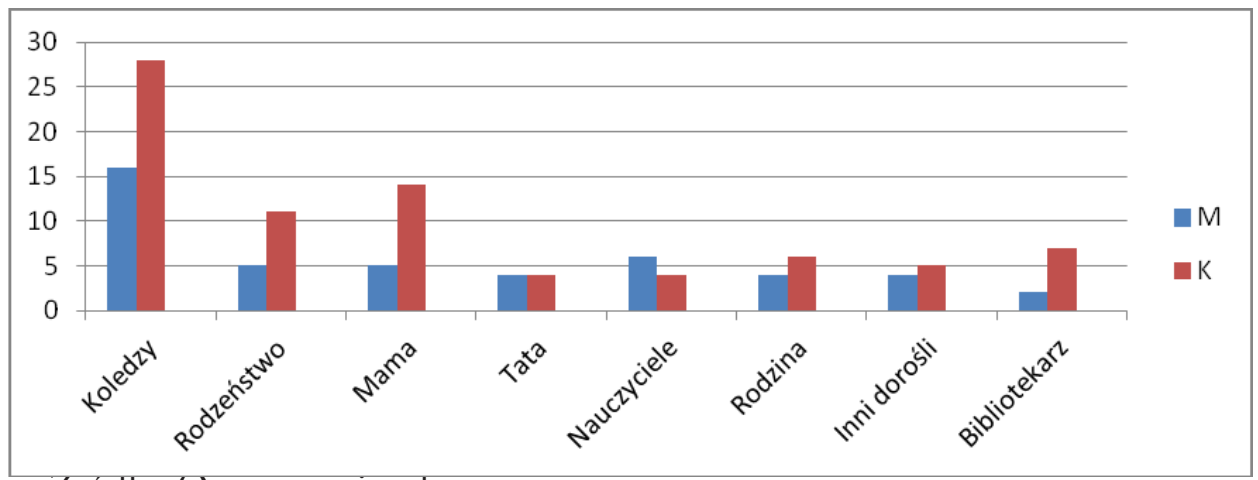

Zródło: Upracowanie własne.

Rys. 10. Ocena zasobów biblioteki szkolnej.

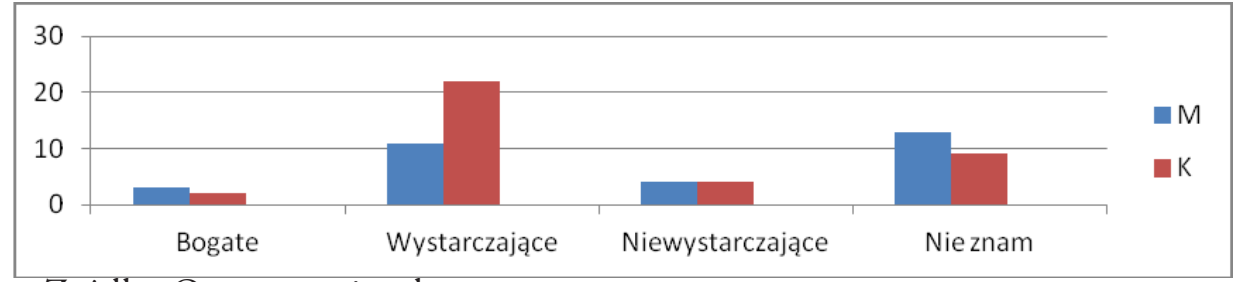

Zródło: Opracowanie własne.

Odpowiedzi na pytanie 7., otwarte, dotyczące wzbogacenia szkolnego księgozbioru udzieliło 26. respondentów, 17 kobiet i 9. mężczyzn. Jedna osoba napisała „nie mam pojęcia”, pozostałe wymieniały rodzaje literatury, a nawet podawały nazwiska autorów. Badani chcieliby, aby uzupełniać zbiory o fantastykę (9), kryminały (5), literaturę młodzieżową (4), biografie (3), powieści przygodowe (3), horrory (2), komiksy (2), zabawne powieści (2), romanse (1), literaturę hobbistyczną (1). Jeśli chodzi o nazwiska, to wskazano następujących pisarzy: Johna Flanagana, Stephena Kinga, Taherek Mafi, G.R.R. Martina, Grahama Mastertona, Katarzynę Berenikę Miszczuk, Remigiusza Mroza, Nel Neuhaus, Ricka Riordana, Andrzeja Sapkowskiego. Młodzież oczekuje zakupu nowości wydawniczych, a jej ulubieni autorzy to twórcy fantastyki i kryminału. Uczniowie potwierdzają zainteresowanie

\footnotetext{
${ }^{3}$ Materiały ze sprawozdania z pracy biblioteki ZSETH w r. szkol. 2017/2018 w posiadaniu autorki.
} 
literaturą gatunkową, przede wszystkim skierowaną do młodzieżowego czytelnika. Minęła już fascynacja powieścią E.L. James 50 twarzy Greya, a na rynku wydawniczym nie pojawił się równie ekscytujący tytuł.

Pytanie 8. dotyczyło oceny kanonu lektur szkolnych, bowiem często w rozmowach uczniowie narzekają, że są one nudne i zniechęcają do czytania. Oceniają więc tę listę średnio i słabo. 13\% wskazało, że jej nie zna (por. Rys. 11).

Rys. 11. Ocena listy lektur szkolnych.

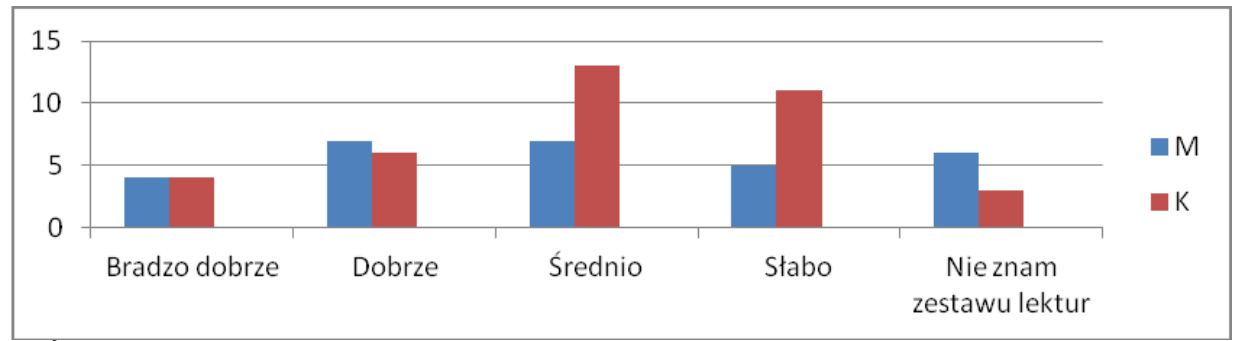

Zródło: Opracowanie własne.

Badani, tak jak poprzednie pokolenia, nie cenią kanonu lektur. Nie zdają sobie sprawy jak wielki kapitał kulturowy zdobywają pokonując kolejne strony, nie zawsze łatwych, dzieł klasyki polskiej i obcej.

Dlatego kolejne, 9. pytanie, dotyczyło wymarzonych lektur szkolnych, tytułów po które uczniowie sięgaliby z przyjemnością. Miało ono charakter otwarty, by umożliwić im swobodną wypowiedź. Odpowiedzi udzieliły 32 osoby (17 kobiet i 15. mężczyzn) co stanowi $47 \%$ respondentów. 10 osób (3 kobiety i 7. mężczyzn) napisało, iż brak jest takich książek, $2(1+1)$ nie wiedzą jakie pozycje chciałyby przeczytać. Zdaniem pozostałych respondentów w kanonie lektur powinny znajdować się książki ciekawe (1), pisane prostym językiem (2), wydane w XXI w. (1) a nie 200 lat temu (1), odpowiednie dla nastolatków (1), a przede wszystkim wciągające (1). Badani zaproponowali konkretne tytuły: Alicję w Krainie Czarów C.S. Lewisa (1), Hobbita (2) i Wtadce pierścieni (1) J.R.R. Tolkiena, Faraona B. Prusa (1), cykl o Harrym Potterze (1), serie „Trylogia Czasu” Kerstin Gier (1) „Niezgodna” Veronici Roth (2), „Delirium” Lauren Olivier (1), „Więzień Labiryntu” Jamesa Dashnera (1). Z autorów wskazali Tahereh Mafi (1) i Nel Neuhaus (1). Wskazali także, że chętnie czytaliby obowiązkowo komiksy (1), powieści fantasy (1), przygodowe (3), biografie sportowców (1), horrory (1). Młodzież chciałaby spędzać przyjemnie czas przygotowując się do lekcji oraz w szkole. Dlatego wskazuje powieści należące do literatury gatunkowej, po którą chętnie sięga.

Pytanie 10. dotyczyło źródeł pozyskiwania książek, które młodzież czyta w wolnym czasie. Rys. 12 pokazuje, że kobiety są aktywniejszymi czytelniczkami niż 
mężczyźni, 7 respondentów nie udzieliło odpowiedzi na to pytanie. Należy domniemywać, iż w wolnym czasie nie czytają. Uczennice ZSETH najczęściej czytają książki znajdujące się w domu (21) i te, które kupiły samodzielnie (21). Kupowanie książek deklaruje dwa razy więcej kobiet (21) niż mężczyzn (10). Znacznie częściej pożyczają one książki od swoich rówieśników (18) niż ich koledzy (2). Respondenci obu płci chętniej niż biblioteki szkolne odwiedzają biblioteki publiczne, które oferują im lepszy dostęp do nowości wydawniczych. Internet nie jest dla nich wiodącym źródłem pozyskiwania książek, jedynie 19\% badanych deklaruje, że ściąga je z Internetu. Natomiast nikt z ankietowanych nie korzysta z innych bibliotek, poza dwoma typami wymienionymi w pytaniu.

Rys. 12. Źródła pozyskiwania książek czytanych w wolnym czasie.

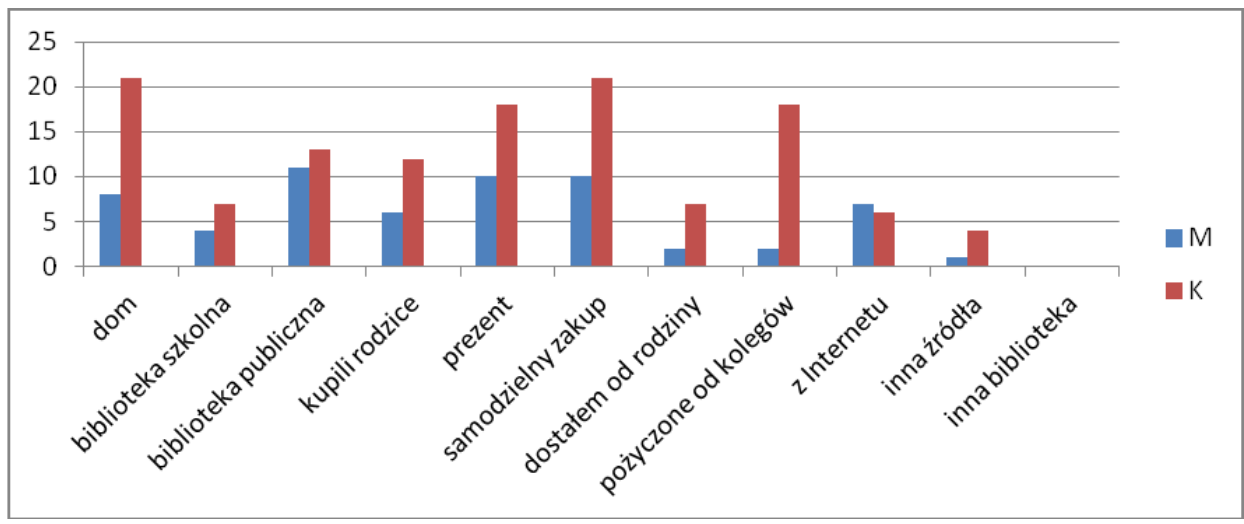

Źródło: Opracowanie własne.

Księgozbiory domowe, własne i rówieśników, są głównym źródłem pozyskiwania książek do czytania. Wzrasta znaczenie bibliotek publicznych, które zmieniły swoje oblicze, i posiadają w ofercie coraz więcej tytułów odpowiadających zainteresowaniom czytelników.

Jeśli uczniowie czytają teksty w formie elektronicznej (pytanie 11) to najczęściej czynią to wykorzystując telefon komórkowy (27 kobiet i 17. mężczyzn). Na tablecie czyta 7 kobiet, na laptopie - 5. Mężczyźni wolą komputer stacjonarny (6), (kobiety nie wskazały tego urządzenia), na tablecie czyta dwóch, z laptopa korzysta jeden. Tylko jedna uczennica z badanej grupy wykorzystuje czytnik e-booków. Nie czyta elektronicznie 15 respondentów (4 kobiety i 11 mężczyzn).

Na kształtowanie nawyków czytelniczych wpływa również zachęta ze strony rodziców, może ona przejawiać się zarówno w namawianiu dzieci do sięgania po książkę (pytanie 12), jak i poprzez kupowanie im książek do czytania (pytanie 13). 
Rys. 13. Czy rodzice zachęcają do czytania?

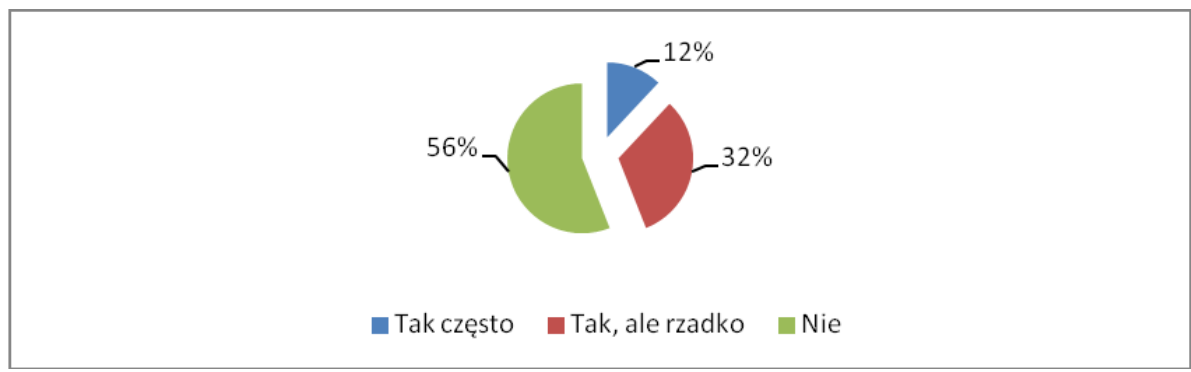

Źródło: Opracowanie własne.

Rodzice $12 \%$ badanych często zachęcają ich do czytania. $32 \%$ respondentów jest rzadko zachęcanych do czytania, 56\% nie jest wcale zachęcanych (por. Rys. 13). Książka nie jest rzeczą często kupowaną pociechom, choć częściej otrzymują ja dziewczęta niż chłopcy (por. Rys. 14). Jedynie 1 uczeń i 7 uczennic deklaruje, że rodzice kupują im często książki do czytania. 33 osobom rodzice nie kupują książek do czytania, a wobec 22 czynią to rzadko. Częściej kupują książki córkom niż synom.

Rys. 14. Czy rodzice kupują książki do czytania?

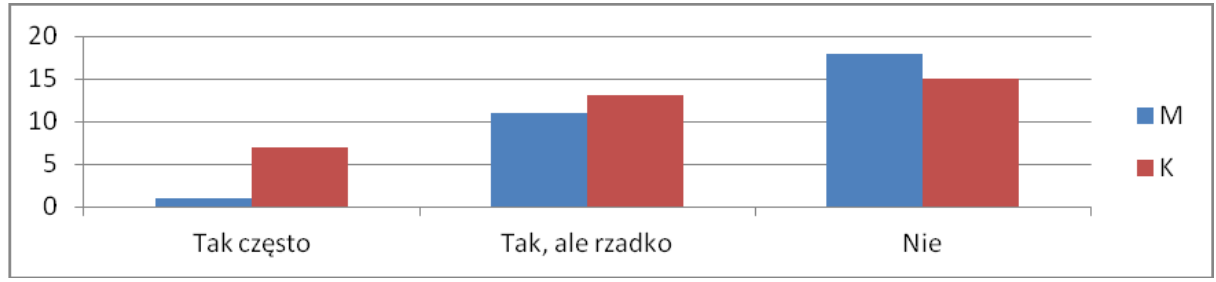

Źródło: Opracowanie własne.

Istotny wpływ na kształtowanie kultury czytelniczej ma środowisko rodzinne. Na zakupy książek ma wpływ kondycja finansowa rodziny (książki są drogie, wydatki na kulturę przegrywają z innymi potrzebami). Natomiast zachęcanie do czytania nic nie kosztuje, a tak duży odsetek uczniów nie jest doń zachęcany. Wynik tego cząstkowego badania rodzi pytania, jakie znaczenie dla rodziców respondentów ma czytanie książek?

Ostatnie, 15. pytanie brzmiało „czy książka to dobry prezent dla ciebie?”. Z grona respondentów 32. badanych (24 kobiety i 8. mężczyzn) uważa, że jest to dla nich dobry prezent, 36 osób (15 kobiet i 21. mężczyzn) jest przeciwnego zdania. Biorąc pod uwagę kryterium płci, książkami chcą być obdarowywane kobiety, dla mężczyzn należy szukać innych prezentów (por. Rys. 15). Dla respondentów wchodzących $\mathrm{w}$ dorosłość książka przestaje być pożądanym prezentem. 
Rys. 15. Czy książka to dobry prezent dla ciebie?

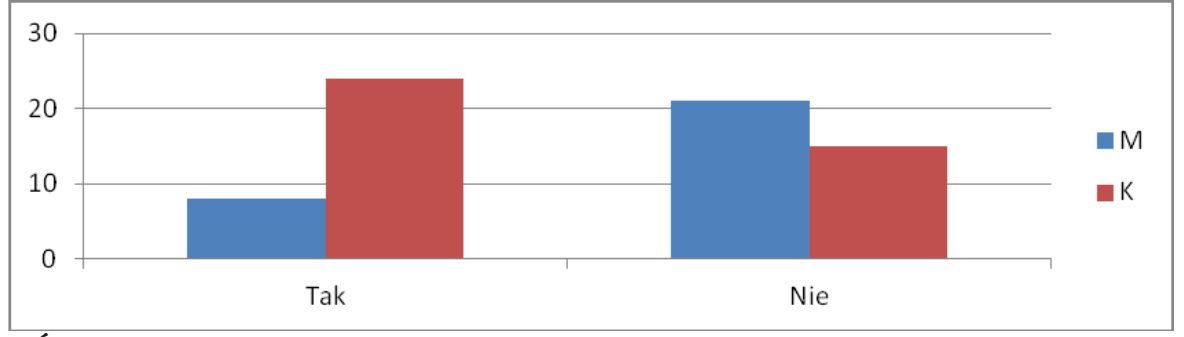

Źródło: Opracowanie własne.

\section{Podsumowanie}

Przeprowadzone wśród uczniów Zespołu Szkół Ekonomiczno-Turystyczno-Hotelarskich im. Władysława Grabskiego w Łodzi badanie ankietowe potwierdziło, że kobiety są aktywniejszymi czytelnikami niż mężczyźni. Ci ograniczają swoją aktywność lekturową i przeważają w grupach czytelników sporadycznych i systematycznych. Praktyki lekturowe uznawane za czytelnictwo intensywne jest domeną kobiet. Choć księgozbiory domowe nie są, według szacunków respondentów liczne, to stanowią główne źródło pozyskiwania książek do czytania. W następnej kolejności kupują interesujące pozycje i pożyczają je od rówieśników. Nie mają jeszcze wyrobionego nawyku korzystania z bibliotek, choć mężczyźni częściej wypożyczają książki w bibliotekach publicznych. Natomiast przedstawiciele obu płci rzadko odwiedzają bibliotekę szkolną.

Respondenci najchętniej sięgają po literaturę gatunkową, preferują fantastykę i powieści kryminalne $e^{4}$. Wybierają współczesnych autorów piszących dla młodzieży, choć nie stronią od pisarzy uznanych jak S. King i popularnych - R. Mróz. Nie lubią czytać lektur szkolnych, które postrzegają jako mało atrakcyjne. W zamian proponują książki, które lubią, napisane prostym językiem i dotyczące interesujących ich problemów. Jeśli czytają teksty elektroniczne to najchętniej wykorzystują telefon komórkowy. Na tym polu kobiety są także aktywniejsze od mężczyzn.

Rodzice nie starają się wpływać na rozwój kultury czytelniczej swoich dzieci. Ponad połowa respondentów nie jest przez nich zachęcana do czytania. Nie kupują im także książek do czytania. Na tym polu dużą rolę odgrywają rówieśnicy, z nimi najczęściej rozmawiają o książkach, pożyczają je od nich. Można także postawić

\footnotetext{
${ }^{4} \mathrm{~W}$ ostatnich latach nie ukazał się tytuł wzbudzający emocje czytelników wszystkich pokoleń jak uczyniła to powieść E.L. James 50 twarzy Greya. Również literatura o wampirach, jak doskonale promowana saga $S$. Meyer, nie budzi dziś takiego zainteresowania i stała się jednym z nurtów fantasy.
} 
hipotezę, że większość samodzielnych zakupów książkowych została dokonana pod wpływem sugestii koleżanek i kolegów. Dla respondentów książka to wciąż dobry prezent. Choć częściej chcą być nimi obdarowywane kobiety.

\title{
Bibliografia
}

Andrzejewska, J. (1988). Definicje pojęć w badaniach czytelnictwa, Roczniki Biblioteczne, 1 ,

Czytelnictwo w ksztatceniu i wychowaniu dzieci (1980). Poznań: IKNiBO.

Dunin, J. (1998). Pismo zmienia świat, Warszawa: PWN.

Encyklopedia oświaty i kultury dorostych (1986), Wrocław: Zakład Narodowy im. Ossolińskich.

Foucault, M. (1977). Archeologia wiedzy, Warszawa: PIW.

Ingarden, R. (1988). O dziele literackim, Warszawa: PWN.

Kłoskowska, A. (1972). Spoteczne ramy kultury, Warszawa: PWN.

Koźmińska, I., Olszewska, E. (2014). $Z$ dzieckiem w świat wartości, Warszawa: Świat Książki.

Muszkowski, J. (1972). Wstęp do socjologii książki, Studia o Książce, 3, 89-152.

Nowe media w komunikacji spotecznej w XX wieku (2005), Warszawa: Oficyna Naukowa.

Papuzińska, J. (1981). Inicjacje literackie, Warszawa: WSiP.

Stan czytelnictwa $w$ Polsce $w 2017$ r. (2018). https://www.bn.org.pl/download/document/1529572435.pdf

Wajda, A. (1979). Metodyka i organizacja czytelnictwa, Bydgoszcz: Wydaw. Uczelniane WSP.

Wojciechowski, J. (2000). Czytelnictwo, Kraków: Wydaw. Uniw. Jagiellońskiego.

\section{Reading Culture of Students of the Władysław Grabski School of Economics, Tourism and Hotel Management in Lodz}

\begin{abstract}
The problem of the reading culture of various groups environments and age constantly interests researchers. Especially that the percentage of readers is decreasing. Currently, only $40 \%$ of Poles read books. Do technical school students want to read books? What are their reading interests? Do parents encourage them to read? These questions were asked in surveys conducted among students of Władysław Grabski School of Economics, Tourism and Hotel Management
\end{abstract}


in Lodz, one of the best high schools in this region and in Poland. The theoretical part of this article focuses on the issues of book culture and reading culture in Poland. It is based on the results of research conducted by the National Library in 2017. Presented data emphasis book interests of respondents at the age 15-24. According to the author's own research, women are intense readers, while men are sporadic or systematic readers. Young readers most often use home libraries or borrow books from their peers. They do not have the habit of using libraries of different types. They read fantasy and crime novels. Unfortunately, parents do not encourage young people to read and do not buy books for them.

Keywords: book interest, reading, young people 